\title{
Whole body elemental composition during drug treatment of rheumatoid arthritis: a preliminary study
}

\author{
A. C. KENNEDY, K. BODDY, E. D. WILLIAMS, A. T. ELLIOTT, \\ I. HARVEY, I. HOLLOWAY, AND J. K. HAYWOOD
}

From the Centre for Rheumatic Diseases, University Department of Medicine, Glasgow Royal Infirmary, and the Health Physics and Nuclear Medicine Unit, Scottish Universities Research and Reactor Centre, East Kilbride, Glasgow

SUMMARY Thirty-two female patients with rheumatoid arthritis were divided into 3 groups and treated for 6 months with prednisolone, depot tetracosactrin, or indomethacin. Their whole body content of calcium, phosphorus, and nitrogen was measured before and after 3 and 6 months' treatment by in-vivo neutron activation analysis. No significant changes in these body elements were observed as a result of the treatments. The average amounts of calcium, phosphorus, and nitrogen were lower than normal in these patients, a finding consistent with the frequent observation of osteoporosis and muscle wasting in rheumatoid arthritis.

Osteoporosis is a common complication of rheumatoid arthritis (Duncan, 1972), and corticosteroid therapy has been implicated as an aggravating factor in producing bone loss in this disease (Mueller, 1976; Kennedy and Lindsay, 1977). Recent evidence (Kennedy et al., 1975, 1976) suggests that bone loss is not due simply to disuse associated with this chronic disease but also to an active process involving major disturbances in calcium metabolism. The nature of this bone loss is of therapeutic importance, but no less important are the rate of bone loss and factors affecting it.

Radiographic and densitometric methods of quantifying bone loss are generally unsatisfactory (Simon, 1965; Aloia et al., 1975). Changes in body content can be studied by metabolic balance methods over short periods of time, but it is not practicable to assess the longer-term changes in body composition by such methods. However, total body invivo neutron activation analysis (TBIVNAA is a technique by which the content of elements in the whole body are estimated. Comparison of such measurements may therefore permit changes in body composition to be detected whatever the period of time during which the changes take place. We

Accepted for publication 27 April 1978

Correspondence to Dr A. C. Kennedy, Centre for Rheumatic Diseases, Baird Street, Glasgow G4 OEH. have used this technique to examine the effects of 2 forms of corticosteroid treatment on the whole body content of calcium, phosphorus, and nitrogen over a period of 6 months. Patients treated with a nonsteroid drug (indomethacin) were also studied for comparison.

\section{Patients}

Thirty-two female patients suffering from definite or classical rheumatoid arthritis (Ropes et al., 1959) were studied. Their ages ranged from 40 to 70 years (mean 54). Each patient was given 1 of 3 treatments: (A) Indomethacin $25 \mathrm{mg}$ orally 3 times daily (12 patients); (B) depot teracosactrin $2 \mathrm{mg}$ by intramuscular injection, twice weekly (10 patients); (C) prednisolone $5 \mathrm{mg}$ orally twice daily (10 patients). No other drug was given during the study period of 6 months. At the end of this time corticosteroid therapy was withdrawn without any adverse effects.

Each patient gave her consent after a full explanation of the implications. The Ethical Committee of Glasgow Royal Infirmary approved the study.

\section{Methods}

Measurements of whole body calcium, phosphorus, and nitrogen were made 1 day before starting treatment and again 3 and 6 months later. For each 
measurement the patient's natural body radioactivity was measured by means of a shadow-shield, scanning-bed whole-body counter (Boddy et al., 1975). The patient was then irradiated while lying on a motor-driven bed which passed between two 14 $\mathrm{MeV}$ sealed-tube neutron generators, mounted one above and one below the patient in a concrete shield (Boddy et al., 1973). The radioactivity induced in the body elements by the irradiation was then measured by the whole-body counter. The counts obtained from each patient were expressed as grams of each element with the use of calibration factors obtained by irradiating a series of water filled anthropomorphic phantoms. Each phantom contained one of the appropriate elements; the procedure used was similar to that described by Williams et al. (1978). The radiation dose to the whole body at the body surface was $1 \mathrm{rem}$, which is comparable to that for many medical $x$-ray investigations.

\section{Results}

Clinical and laboratory findings in the patients are shown in Table 1. The 3 treatment groups were similar in age, rheumatoid factor titre (Ball, 1952), erythrocyte sedimentation rate (Westergren), and functional capacity (Steinbrocker et al., 1949). However, in group B the average duration of disease was less than in the other 2 groups. Articular inde and grip strength were comparable for the $\mathbf{3}$ groups initially and, apart from grip strength in the indors methacin-treated group, improved during treatment

The results of the TBIVNAA measurements calcium, phosphorus, and nitrogen were expresse as ratios of the 3 and 6 months' to the initial measurements (Table 2). Generally, no significant changes in body content of the 3 elements were observed as a result of each treatment, nor were there any significant differences between each treated group. There was 1 exception: in the indomethacing treated group, whole body phosphorus was signf ficantly higher (by $3 \%$ ) at 3 months than its initiag value $(P<0.05), t$ test and Wilcoxon signed ran $\mathrm{R}^{\circ}$ sum test). However, the 6-month result was not significantly different from the initial result.

Since a large number of statistical tests were performed on the data, spurious significant results. (at the $5 \%$ level) were to be expected to $5 \%$ of tests The number of comparisons was therefore reduced. by grouping the data, combining the results for calcium and phosphorus, representing bone minerą elements, and combining results for patients treated with tetracosactrin and prednisolone (both corto costeroids). No differences between treatments of during treatment significant at the $5 \%$ level by $\bar{\Phi}$ tests were then observed.

Table 1 Clinical and laboratory indices for the 3 groups of patients at the start up of the study (mean $\pm S D$ )

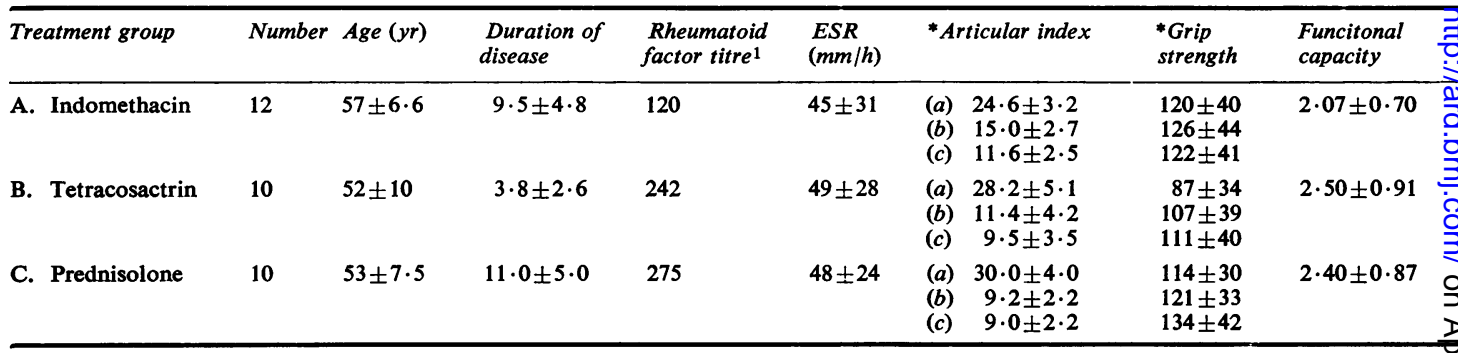

*These results were obtained after $(a) 0,(b) 3$, and $(c) 6$ months' treatment. 1 Reciprocal of titre.

Table 2 Relative amounts of whole body elements after 0, 3, and 6 months' treatment

\begin{tabular}{|c|c|c|c|c|c|c|c|c|c|c|}
\hline Tre & atment & Months & $\begin{array}{l}\text { Calcium } \\
\text { Mean }\end{array}$ & $S E M$ & $\begin{array}{l}\text { Phosphorus } \\
\text { Mean }\end{array}$ & $S E M$ & $\begin{array}{l}\text { Nitrogen } \\
\text { Mean }\end{array}$ & $S E M$ & $\begin{array}{l}\text { Body weight } \\
\text { Mean }\end{array}$ & $S E M$ \\
\hline A. & Indomethacin & $\begin{array}{l}0 \\
3 \\
6\end{array}$ & $\begin{array}{l}1 \cdot 000 \\
1 \cdot 000 \\
1 \cdot 021\end{array}$ & $\begin{array}{l}\overline{0} .026 \\
0.024\end{array}$ & $\begin{array}{l}1 \cdot 000 \\
1 \cdot 031 \\
1 \cdot 009\end{array}$ & $\begin{array}{l}\overline{0} \cdot 012 \\
0.017\end{array}$ & $\begin{array}{l}1 \cdot 000 \\
1 \cdot 002 \\
0 \cdot 994\end{array}$ & $\begin{array}{l}\overline{0} .031 \\
0.029\end{array}$ & $\begin{array}{l}1 \cdot 000 \\
0.992 \\
0.999\end{array}$ & $\begin{array}{l}\overline{0} .008 \\
0.012\end{array}$ \\
\hline B. & $\begin{array}{l}\text { Depot } \\
\text { Tetracosactrin }\end{array}$ & $\begin{array}{l}0 \\
3 \\
6\end{array}$ & $\begin{array}{l}1 \cdot 000 \\
1 \cdot 001 \\
1 \cdot 053\end{array}$ & $\begin{array}{l}\overline{0} .047 \\
0.050\end{array}$ & $\begin{array}{l}1 \cdot 000 \\
1 \cdot 008 \\
0.998\end{array}$ & $\begin{array}{l}\overline{0} .012 \\
0.011\end{array}$ & $\begin{array}{c}1 \cdot 000 \\
1 \cdot 012 \\
0 \cdot 996\end{array}$ & $\begin{array}{l}- \\
0.030 \\
0.039\end{array}$ & $\begin{array}{l}1 \cdot 000 \\
1 \cdot 087 \\
1 \cdot 125\end{array}$ & $\begin{array}{l}- \\
0.029 \\
0.027\end{array}$ \\
\hline C. & Prednisolone & $\begin{array}{l}0 \\
3 \\
6\end{array}$ & $\begin{array}{l}1 \cdot 000 \\
1 \cdot 030 \\
0.969\end{array}$ & $\begin{array}{l}\overline{0} .031 \\
0.019\end{array}$ & $\begin{array}{l}1 \cdot 000 \\
1 \cdot 027 \\
1 \cdot 016\end{array}$ & $\begin{array}{l}-\overline{0} .018 \\
0.021\end{array}$ & $\begin{array}{c}1 \cdot 000 \\
1 \cdot 004 \\
1 \cdot 001\end{array}$ & $\begin{array}{l}\overline{0} .029 \\
0.026\end{array}$ & $\begin{array}{l}1 \cdot 000 \\
1 \cdot 046 \\
1 \cdot 052\end{array}$ & $\begin{array}{l}\overline{0} \\
0.022 \\
0.019\end{array}$ \\
\hline
\end{tabular}

SEM = standard error of mean. 
Table 3 Details of patients whose whole body elemental compositions were compared

\begin{tabular}{|c|c|c|c|c|c|c|c|}
\hline \multirow[t]{2}{*}{ Patient group } & \multirow[t]{2}{*}{ Number } & \multicolumn{2}{|c|}{ Height $(m)$} & \multicolumn{2}{|c|}{ Weight $(k g)$} & \multicolumn{2}{|c|}{ Age $(y r)$} \\
\hline & & Mean & Range & Mean & Range & Mean & Range \\
\hline $\begin{array}{l}\text { Rheumatoid arthritis } \\
\text { Hypertension }\end{array}$ & $\begin{array}{l}32 \\
23\end{array}$ & $\begin{array}{l}1.58 \\
1.59\end{array}$ & $\begin{array}{l}1 \cdot 44-1 \cdot 72 \\
1.48-1.67\end{array}$ & $\begin{array}{l}58 \cdot 7 \\
64 \cdot 1\end{array}$ & $\begin{array}{l}39-92 \\
44-80\end{array}$ & $\begin{array}{l}54 \\
52\end{array}$ & $\begin{array}{l}40-70 \\
40-70\end{array}$ \\
\hline
\end{tabular}

Table 4 Comparison of elemental contents (in grams) of patients with rheumatoid arthritis and with hypertension

\begin{tabular}{|c|c|c|c|c|c|c|}
\hline Patient group & Calcium & & Phosphor & & Nitrogen & \\
\hline & Mean & $S D$ & Mean & $S D$ & Mean & $S D$ \\
\hline $\begin{array}{l}\text { Rheumatoid arthritis (RA) } \\
\text { Hypertension (H) } \\
\text { Ratio: RA/H } \\
\text { Significance level of } \\
\text { difference }\end{array}$ & $\begin{array}{l}660 \\
803 \\
0.82 \\
P<0.001\end{array}$ & $\begin{array}{l}124 \\
100\end{array}$ & $\begin{array}{l}412 \\
462 \\
0.89 \\
P<0.01\end{array}$ & $\begin{array}{l}71 \\
58\end{array}$ & $\begin{array}{l}1120 \\
1280 \\
0.87 \\
P<0.001\end{array}$ & $\begin{array}{l}144 \\
156\end{array}$ \\
\hline
\end{tabular}

The measurements of whole body elements in the patients before treatment were compared with those which would be expected in subjects not suffering from rheumatoid arthritis. The comparison was made with measurements on 23 females suffering from hypertension from various causes who were examined in another investigation (Boddy et al., 1978). We have no reason to suppose that such patients would have abnormal contents of calcium, phosphorus, or nitrogen, and the average amount of calcium was similar to that predicted for normal persons of similar stature by Ellis and Cohn, (1975). The 2 groups were well matched for height, weight, and age (Table 3). The patients with rheumatoid arthritis had significantly less calcium, phosphorus, and nitrogen than those with hypertension (Table 4).

\section{Discussion}

In this study of patients with rheumatoid arthritis no significant changes in calcium and phosphorus, the major constituents of bone mineral, were seen. Since the development of osteoporosis is often associated with loss of bone of only a few percent per year (Dent, 1969), changes would have been detectable in 6 months only if treatment substantially accelerated the loss. Measurements over a longer period may be more revealing.

In the patients treated with prednisolone and tetracosactrin there was on average an increase in body weight, whereas indomethacin-treated patients maintained constant weight. In patients whose body weight increased greatly an increase in body nitrogen was also observed, although by a smaller percentage. There may therefore be some increase in lean body mass resulting from amelioration of the disease, though in other clinical contexts these drugs have a catabolic effect. Possibly the beneficial anti-inflammatory properties of corticosteroids outweighed the catabolic effects. though this hypothesis conflicts with the findings of Sprague (1950) of persistent protein catabolism in patients with rheumatoid arthritis treated with corticosteroids. However, most of the weight gain was probably due to increased body fat and water retention (Ernest, 1967).

The deficits in calcium and phosphorus, of $18 \%$ and $11 \%$ respectively, compared to the amounts in the patients with hypertension, are similar to the deficit of $18 \%$ found by Cohn et al. (1974) in females with osteoporosis. Loss of bone mineral is recognised as a common feature of rheumatoid arthritis. The association of pain and disease (Duncan, 1972) might also be expected to result in a diminution of muscle mass. This could explain why the average nitrogen content of these patients was $13 \%$ less than those with hypertension.

Two conclusions have been drawn from this study. First, patients suffering from rheumatoid arthritis have relatively low contents of calcium, phosphorus, and nitrogen. Secondly, the fact that changes in these elements were not detected during 6 months' treatment with corticosteroids suggests that no dramatic changes took place (an average change of about $7 \%$ or more would have been detected), and that if there were changes in the elements measured the period of the study was too short to have detected them. Nevertheless, the technique of TBIVNAA is well suited to longer-term studies of this nature.

We are indebted to Professor W. Watson Buchanan for advice and support. This work was made possible by grants from the Medical Research Council to A.C.K. and K.B. 


\section{References}

Aloia, J. F., Ellis, K., Zanzi, I., and Cohn, S. H. (1975). Photon absorptiometry and skeletal mass in the treatment of osteoporosis. Journal of Nuclear Medicine, 16, 196-199.

Ball, J. (1952). Sheep cell agglutination test for rheumatoid arthritis. A clinico-pathological study. Annals of the Rheumatic Diseases, 11, 97-111.

Boddy, K., Brown, J. J., Davies, D. L., Elliott, A., Harvey, I., Haywood, J. K., Holloway, I., Lever, A. F., Robertson, J. I. S., and Williams, E. D. (1978). Concurrent estimation of total body and exchangeable body sodium in hypertension. Clinical Science and Molecular Medicine, 54, 187-191.

Boddy, K., Elliott, A., Robertson, I., Mahaffy, M. E., and Holloway, I. (1975). A high sensitivity dual-detector shadow shield whole-body counter with an 'invariant' response for total body IN vivo neutron activation analysis. Physics in Medicine and Biology, 20, 296-304.

Boddy, K., Holloway, I., and Elliott, A. (1973). A simple facility for total body IN vivo activation analysis. International Journal of Applied Radiation and Isotopes, 24, 428-430.

Cohn, S. H., Ellis, K. J., Wallach, S., Zanzi, I., Atkins, H. L. and Aloia, J. F. (1974). Absolute and relative deficit in total skeletal calcium and radial bone mineral in osteoporosis. Journal of Nuclear Medicine, 15, 428-435.

Dent, C. E. (1969). Ageing of Connective and Skeletal Tissue Osteoporosis a THULE International Symposium, p. 261 Nordiska Bokhandelns Stockholm.

Duncan, H. (1972). Osteoporosis in rheumatoid arthritis and corticosteroid induced osteoporosis. Orthopedic Clinics of North America, 3, 571-583.

Ellis, K. J., and Cohn, S. H. (1975). The correlation between skeletal mass and muscle mass in man. Journal of Applied Physiology, 38, 455-460.
Ernest, I. (1967). Changes in body composition after therae peutically induced remission in 12 cases of Cushing syndrome. Acta Endocrinologica, 54, 411-427.

Kennedy, A. C., Allam, B. F., Boyle, I. T., Nuki, G., Roonexp P. J., and Buchanan, W. W. (1975). Abnormalities if mineral metabolism suggestive of parathyroid overactivit in rheumatoid arthritis. Current Medical Research ant Opinion, 3, 345-358.

Kennedy, A. C., and Lindsay, R. (1977). Bone involvemen in rheumatoid arthritis. Clinics in Rheumatic Disease 3, 403-420.

Kennedy, A. C., Lindsay, R., Buchanan, W. W., and Allan B. F. (1976). Bone resorbing activity in the sera of patients with rheumatoid arthritis. Clinical Science and Molecular Medicine, 51, 205-207.

Mueller, M. N. (1976). Effects of corticosteroids on bonet mineral in rheumatoid arthritis and asthma. America $\bar{D}$ Journal of Roentgenology, Radium Therapy and Nuclea Medicine, 126, 1300.

Ropes, M. W., Bennett, G. A., Cobb, S., Jacox, R., and̂ Jessar, A. R. (1959). Proposed diagnostic criteria fow rheumatoid arthritis. Annals of the Rheumatic Diseases, $18,49$.

Simon, G. (1965). Principles of Bone X-ray Diagnosis, 2nd ed., p. 159. Butterworth: London.

Sprague, R. G. (1950). Cortisone and ACTH in clinica medicine. Proceedings of the Staff Meetings of the May $\overline{\bar{\sigma}}$ Clinic, 25, 500-502.

Steinbrocker, O., Traeger, C. H., and Batterman, K. Co (1949). Therapeutic criteria in rheumatoid arthritis. Journal of the American Medical Association, 140, 659 665 .

Williams, E. D., Boddy, K., Harvey, I., and Haywood, J. Kอ (1978). Calibration and evaluation of a scanning systerf for total body IN vivo activation analysis using $14 \mathrm{Me}$ neutrons. Physics in Medicine and Biology, in press. 